\title{
Erratum to: PDK1-mTOR signaling pathway inhibitors reduce cell proliferation in MK2206 resistant neuroblastoma cells
}

\author{
Lei Qi ${ }^{1}{ }^{2 *}$, Hidemi Toyoda ${ }^{1}$, Dong-qing Xu ${ }^{1,2}$, Ye Zhou ${ }^{3}$, Naoto Sakurai ${ }^{1}$, Keishirou Amano ${ }^{1}$, Kentaro Kihira ${ }^{1}$, \\ Hiroki Hori', Eiichi Azuma ${ }^{1}$ and Yoshihiro Komada ${ }^{1 *}$
}

\section{Erratum to: Cancer Cell Int (2015) 15:91 DOI 10.1186/s12935-015-0239-4}

Unfortunately, the original version of this article [1] contained an error. After publication it came to the authors' attention that the figure legends were displayed incorrectly. The correct figure legends can be found below in this erratum.

Fig. 1 MK-2206 suppressed the cell growth of NB cells. a MK-2206 suppressed the cell growth of NB cell lines. LAN-1, KP-N-SIFA, NB-19, and SK-N-DZ cells were cultured in RPMI1640 + 10 \% FBS with MK-2206 at indicated concentrations. Cell growth was evaluated as cell numbers at $72 \mathrm{~h}$, and it was repeated three times. Data are expressed as the mean $( \pm \mathrm{SD})$. b Photomicrographs of MK-2206 non-resistant and resistant cells. Cells were cultured in glass bottom slide chambers with RPMI1640 + 10 \% FBS, with MK-2206 (resistant sublines)/without MK-2206 (non-resistant cells) overnight. A $50 \mu \mathrm{m}$ scale is indicated (Olympus Fluoview fv1000, DIC acquisition, $\times 40$ ). c MK-2206 showed less inhibition in the proliferation of MK-2206-resistant sublines than in the non-resistant cells. Indicated cells were cultured in RPMI1640 + 10 \% FBS with MK-2206 at indicated concentrations. Cell growth was evaluated as cell numbers at indicated hours, and it was repeated three times. Data are expressed as the mean $( \pm \mathrm{SD}) .{ }^{*} \mathrm{P}<0.01$

Fig. 2 MK-2206 showed less inhibition in cell growth of MK-2206-resistant sublines. a MK2206 suppressed cell growth in a dose dependent method, and MK-2206-resistant sublines maintained resistance after 2-week

\footnotetext{
*Correspondence: chylae2003@hotmail.com;

komada@clin.medic.mie-u.ac.jp

${ }^{1}$ Department of Pediatrics and Developmental Science, Mie University Graduate School of Medicine, 2-174 Edobashi, Tsu, Mie 514-8507, Japan Full list of author information is available at the end of the article
}

withdrawal of MK-2206. Indicated cells were cultured in RPMI1640 + $10 \%$ FBS with MK-2206 at the indicated concentrations. Cell growth was evaluated as cell numbers at $72 \mathrm{~h}$, and it was repeated three times. Data are expressed as the mean $( \pm \mathrm{SD})$. b IC50 of MK-2206 in indicated cells. c The effect of MK-2206 on cell cycle phase distribution. LAN-1 and LAN-1-MK were treated with/ without MK-2206 $(5 \mu \mathrm{M})$ in RPMI1640 with $10 \%$ FBS for $12 \mathrm{~h}$ followed by analysis of cell cycle phase distribution, as introduced in "Methods". Cells were stained with propidium iodide (PI) for 30 min followed by FACScan flow cytometer. d Column chart of cell cycle distribution in $\mathbf{c}$

Fig. 3 Effect of GSK2334470 (GSK), PDK1 inhibitor, in MK-2206-resistant sublines compared with non-resistant cells. a Indicated cells were treated with GSK at indicated concentrations, with/without MK-2206 $(5 \mu \mathrm{M})$ in RPMI1640 + $10 \%$ FBS. Cell growth was evaluated as cell numbers at $72 \mathrm{~h}$, and it was repeated three times. Data are expressed as the mean $( \pm \mathrm{SD})$. b IC50 of GSK in indicated cells. c The effect of GSK on cell cycle phase distribution in LAN-1 and LAN-MK. LAN-1 and LAN-1-MK were treated with GSK $(5 \mu \mathrm{M})$ with/without MK-2206 $(5 \mu \mathrm{M})$ in RPMI1640 with $10 \%$ FBS for $12 \mathrm{~h}$ followed by analysis of cell cycle phase distribution, as introduced in "Methods". Indicated cells were stained with PI for 30 min followed by FACScan flow cytometer

Fig. 4 Effect of AZD8055 (AZD), mTOR inhibitor, in MK2206 resistant sublines compared with non-resistant cells. a Indicated cells were treated with AZD at indicated concentrations, with/without MK-2206 $(5 \mu \mathrm{M})$ in RPMI1640 + $10 \%$ FBS. Cell growth was evaluated as cell numbers at $72 \mathrm{~h}$, and it was repeated three times. Data are expressed as the mean $( \pm \mathrm{SD})$. $\mathbf{b}$ IC50 of AZD in indicated cells. c The effect of AZD on cell cycle phase distribution in LAN-1 and LAN-MK. LAN-1 and LAN-1-MK 
were treated with AZD (50 nM) with/without MK-2206 $(5 \mu \mathrm{M})$ in RPMI1640 with $10 \%$ FBS for $12 \mathrm{~h}$ followed by analysis of cell cycle phase distribution, as introduced in "Methods". Indicated cells were stained with PI for 30 min followed by FACScan flow cytometer

Fig. 5 Effect of GSK2334470 (GSK) on PDK1-mTORS6K axis in MK-2206-resistant sublines. a-d After $1 \mathrm{~h}$ serum starvation, indicated cells were incubated in RPMI1640 + $10 \%$ FBS with/without MK-2206 $(5 \mu \mathrm{M})$ or GSK $(5 \mu \mathrm{M})$. Phosphorylation of PDK1, AKT, mTOR, and S6K were detected by western blot at 1.5 and $12 \mathrm{~h}$, so were AKT and Actin. GSK3 $\beta$, p-GSK3 $\beta$ and N-MYC were also detected

\section{Author details}

${ }^{1}$ Department of Pediatrics and Developmental Science, Mie University Graduate School of Medicine, 2-174 Edobashi, Tsu, Mie 514-8507, Japan.
2 Department of Pediatrics, Xin Hua Hospital Affiliated to Shanghai Jiao Tong University School of Medicine, 1665 Kong Jiang Road, Shanghai 200092,

China. ${ }^{3}$ Department of Child Health Nursing, Mie University Graduate School of Medicine, 2-174 Edobashi, Tsu, Mie 514-8507, Japan.

The online version of the original article can be found under doi:10.1186/s12935-015-0239-4.

Received: 21 October 2015 Accepted: 5 November 2015

Published online: 17 November 2015

\section{Reference}

1. Qi L, Toyoda H, Xu D, Zhou Y, Sakurai N, Amano K, Kihira K, Hori H, Azuma E, Komada Y, et al. PDK1-mTOR signaling pathway inhibitors reduce cell proliferation in MK2206 resistant neuroblastoma cells. Cancer Cell International. 2015;15:91.

\section{Submit your next manuscript to BioMed Central and take full advantage of:}

- Convenient online submission

- Thorough peer review

- No space constraints or color figure charges

- Immediate publication on acceptance

- Inclusion in PubMed, CAS, Scopus and Google Scholar

- Research which is freely available for redistribution

Submit your manuscript at www.biomedcentral.com/submit 